\title{
ASSESSMENT OF WATER IN INTEGRATED ECOSYSTEM ACCOUNTING
}

\author{
DOI: http://dx.doi.org/10.18509/GBP.2020.29
}

UDC: $657: 502.14]: 627$

\section{Nikolay Katsarski}

Sofia University „St. Kliment Ohridski“, Faculty of Geology and Geography, Department "Regional Development", Bulgaria

\begin{abstract}
The assessment of ecosystem assets is one of the most important method of developing the ecosystem at all. It gives the opportunity to calculate the services which must be done by humans making assets regenerate by itself. The methods for assessing the ecosystem services include biophysical methods, socio-cultural methods, economic methods and expert-based quantification. All of these methods should be used together. This is because of the relationship with the specific feature of the asset and the ecosystem services that are used for producing it. The assessment of the water can be presented like natural water /ocean, lakes, under earth, rivers etc./ and water like a resource /material for production of products/. Assessing the ecosystems related with water is complex concept. They are changing by different factors both human and natural. The assessing process of ecosystem assets in monetary term lies on the accounting methodology. Therefore, some assets related with water can be calculated and others not.
\end{abstract}

Keywords: water assessment, water, ecosystem accounting

\section{INTRODUCTION}

Ecosystem accounts are the main source of information about our environment. They generate non-financial and financial information that helps to analyze vital resources such as air, water, soil and more. This analysis is caused by the increasingly difficult opportunity for nature to reproduce itself. This necessitates further human effort to enrich these resources. Nowadays, we are faced with a number of activities that pollute, create catastrophic risks, extract resources from the earth's interior, create artificial ecosystem assets that change the environment, build different infrastructure for everyday life and industry, etc. These activities are the necessary "evil" for humanity's existence. But it does affect our environment. The risks associated with this are water pollution, soil pollution, disturbance of natural water runoff, gassing, flooding of territories (residential, agricultural, industrial), loss of resources in their natural environment, etc. This is quite abstract, as no current assessment of natural resources is made in material and monetary aspects. The following questions are relevant to this assessment: 1 . What do we measure? 2. How do we measure? The answers to the questions are sought in the application of different methods of valuing ecosystem assets. Valuation as a method of accounting science is associated with determining the value of an asset at a particular point in time, taking into account its particular features and useful life. The calculation is another method that relates to determining the value of an asset when it is initially acquired. These are actions that involve calculating all the costs of acquiring / building / an asset before putting it into operation. Valuing ecosystem assets is an important point in maintaining, expanding, reproducing and using them. 


\section{The need for water assessment}

The waters as a major source of life on our planet must be rigorously monitored and evaluated. The need for water assessment lies in its use for domestic and industrial purposes, on the one hand. On the other hand, it is associated with cultural and heritage features that have played historically. All this is relevant for adequate resource management, analysis of different policies, development indicators, strategies for sustainable development.

The need for adequate water management is becoming increasingly felt. This is due to the industrial progress of developed countries. In addition, the gradual transition to renewable energy and the creation of hydropower plants requires the use of water as a resource. The construction of artificial swimming pools in certain places is a typical example of water provisioning and their specific use. Water management includes dams and all the infrastructure that helps reach this resource to the population and industry. It should be responsible for a number of activities, such as increasing the water supply, proper distribution between the population and industry, replacing the entire infrastructure/water supply system, treatment plants, shut-off and redistributing cranes, etc. /. All this has to do with the management of a solid financial resource. Therefore, the assessment of the infrastructure already created is important for the future policy of the state. Allocating additional financial resources is a matter of state policy. State policy towards industry requires a significant volume of water, while migration of the population from one region to another is much smaller. However, state policies with new reservoirs, water conservation and access to water resources can most easily be sought through economic development indicators. The use of statistical institutes in different countries creates information that serves to analyze the extent to which water is used, which water is used (groundwater and groundwater), which sectors use the most, at what rate water flows. It is this information that is used to identify sustainable water development strategies. The analysis of this information and, above all, its authenticity is of paramount importance for the independence of a country. In this connection, the following more important aspects can be distinguished:

- „Resource management - can be improved through the ability to assess the physical extent of environmental depletion and degradation.

- Policy analysis - natural resource accounts help analyse the effectiveness of current economic and environmental policies. They provide the information needed for making better use of our resources by analysing sectoral economic performance and measuring total natural wealth.

- Indicator development - accounting data can be expressed in alternative ways or can be integrated with economic and social statistics to compile indicators. For example, a comparison of the proportions of indigenous and exotic forests, or carbon dioxide equivalent emissions per unit of groos domestic product.

- Sustainable development strategies and policies - information about environmental and economic interactions help improve sustainable development strategies and policies." $[1]$

The need for adequate water management is becoming increasingly felt. This is due to the industrial progress of developed countries. In addition, the gradual transition to renewable energy and the creation of hydropower plants requires the use of water as a resource. The construction of artificial swimming pools in certain places is a typical example of water provisioning and their specific use. Water management includes dams and all the infrastructure that helps reach this resource to the population and industry. 
Determining the value of these ecosystem assets is a complex process, given that they were built many years ago and there is no adequate value assessment. The cost of maintaining and replacing the entire infrastructure is important here. Next, the calculation of water for the population and industry determines its consumption. The more expensive the consumption, the lower it will be and the lower the consumption will be. Price also directly affects the economy, as a material that serves to dissolve a number of liquids. Consumers are the ones who pay the final price, which directly affects the country's gross domestic product.

The need to evaluate and calculate ecosystem assets is needed to determine the value of overall infrastructure, to outline government policies, to identify strategic goals for sustainable development, and to identify appropriate indicators for measuring the economy by statistical offices. Therefore, the methods of estimating and calculating water are of the utmost importance in the analysis and interpretation of data.

\section{Water assessment methods}

Ecosystem assessment methods are a complex mechanism that deserves a comprehensive view from different perspectives. The assessment of water, as well as ecosystem accounts, should be considered in a given aspect. The first is physical assessments that involve assessing the condition over a period of time. "Whatever the physical measurement unit used for a particular asset, several important points should be noted:

- the units should be consistent and comparable over time

- different assets can have different physical units of measurement

- a stock account can be compiled, for example, by quality classes, species, or ownership

- not all assets can have total stock volumes because they are not available or particularly useful, for example, soil and water" [2]

With the advent of technology, the analysis of the physical state of water will increasingly make use of smart technologies. Building smart cities is a fact. This will create conditions for constant monitoring of the physical state of the waters, and not only. „Smart cities in economic and social terms are looking to the future. They are constantly monitoring the most important infrastructure - roads, bridges, tunnels, railways, metro, airports, seaports, communication systems, water supply, power supply, even important buildings - for optimal resource allocation and safety.“ "[3]

In addition to the physical analyzes used, economic assessment and analysis methods are also used. Table 1 presents the valuation methods and their use.

Table 1. Summary of valuation methods and their use in ecosystem accounting [4]

\begin{tabular}{|c|c|c|c|}
\hline Valuation method & Description & Comments & \begin{tabular}{|l|} 
Suitability for \\
ecosystem \\
accounting
\end{tabular} \\
\hline Unit resource rent & $\begin{array}{l}\text { Prices determined by } \\
\text { deducting costs of } \\
\text { labour, produced assets } \\
\text { and intermediate inputs } \\
\text { from market price of } \\
\text { outputs (benefits). }\end{array}$ & $\begin{array}{l}\text { Estimates will be affected by the } \\
\text { property rights and market } \\
\text { structures surrounding production. } \\
\text { For example, open access fisheries } \\
\text { and markets for water supply often } \\
\text { generate low or zero rents. }\end{array}$ & $\begin{array}{lr}\text { In principle } & \text { this } \\
\text { method } & \text { is } \\
\text { appropriate but } & \text { bution of } \\
\text { consideration } & \text { market structures is } \\
\text { required. }\end{array}$ \\
\hline $\begin{array}{l}\text { Production function, } \\
\text { cost function and profit } \\
\text { function methods }\end{array}$ & $\begin{array}{l}\text { Prices obtained by } \\
\text { determining } \\
\text { contribution of the } \\
\text { ecosystem to a market } \\
\text { based price using an }\end{array}$ & $\begin{array}{l}\text { In principle analogous to resource } \\
\text { rent but generally focused on the } \\
\text { valuation of regulating services. } \\
\text { May be difficult to estimate the } \\
\text { functions. }\end{array}$ & $\begin{array}{l}\text { Appropriate } \\
\text { provided the market } \\
\text { based price being } \\
\text { decomposed refers } \\
\text { to a product rather }\end{array}$ \\
\hline
\end{tabular}




\begin{tabular}{|c|c|c|c|}
\hline & $\begin{array}{l}\text { assumed production, } \\
\text { cost or profit function. }\end{array}$ & & $\begin{array}{l}\text { than an asset }- \text { e.g. } \\
\text { value of housing } \\
\text { services rather than } \\
\text { the value of a } \\
\text { house. }\end{array}$ \\
\hline $\begin{array}{l}\text { Payment for Ecosystem } \\
\text { Services (PES) schemes }\end{array}$ & $\begin{array}{l}\text { Prices are obtained from } \\
\text { markets for specific } \\
\text { regulating services (e.g. } \\
\text { in relation to carbon } \\
\text { sequestration) }\end{array}$ & $\begin{array}{l}\text { Estimates will be affected by the } \\
\text { type of market structures put in } \\
\text { place for each PES }\end{array}$ & $\begin{array}{l}\text { Possibly } \\
\text { appropriate } \\
\text { depending on the } \\
\text { nature of the } \\
\text { market structures. }\end{array}$ \\
\hline Hedonic pricing & $\begin{array}{l}\text { Prices are estimated by } \\
\text { decomposing the value } \\
\text { of an asset (e.g. a house } \\
\text { block including the } \\
\text { dwelling and the land) } \\
\text { into its characteristics } \\
\text { and pricing each } \\
\text { characteristic through } \\
\text { regression analysis }\end{array}$ & $\begin{array}{l}\text { Very data intensive approach and } \\
\text { separating out the effects of } \\
\text { different characteristics may be } \\
\text { difficult, unless there are large } \\
\text { sample sizes. }\end{array}$ & $\begin{array}{l}\text { Appropriate in } \\
\text { principle. Heavily } \\
\text { used in the pricing } \\
\text { of computers in } \\
\text { the national } \\
\text { accounts. }\end{array}$ \\
\hline Replacement cost & $\mid$\begin{tabular}{lrr} 
Prices & reflect & the \\
estimated & cost & of \\
replacing & a & specific \\
ecosystem & \multicolumn{3}{r}{ services } \\
using produced & assets \\
and associated inputs.
\end{tabular} & $\begin{array}{l}\text { This method requires an } \\
\text { understanding of the ecosystem } \\
\text { function underpinning the supply } \\
\text { of the service and an ability to find } \\
\text { a comparable "produced" method } \\
\text { of supplying the same service. }\end{array}$ & $\begin{array}{l}\text { Appropriate } \\
\text { under the } \\
\text { assumptions (i) } \\
\text { that the estimation } \\
\text { of the costs reflects } \\
\text { the ecosystem } \\
\text { services being lost; } \\
\text { (ii) that it is a least- } \\
\text { cost treatment; } \\
\text { and (iii) that it } \\
\text { would be expected } \\
\text { that society would } \\
\text { replace the service } \\
\text { if it was removed. } \\
\text { (Assumption (iii) } \\
\text { may be tested } \\
\text { using stated } \\
\text { preference } \\
\text { methods.) }\end{array}$ \\
\hline Damage costs avoided & $\begin{array}{l}\text { Prices are estimated in } \\
\text { terms of the value of } \\
\text { production losses or } \\
\text { damages that would } \\
\text { occur if the ecosystem } \\
\text { services were reduced or } \\
\text { lost due to ecosystem } \\
\text { changes (e.g. as a result } \\
\text { of pollution of } \\
\text { waterways). }\end{array}$ & $\begin{array}{l}\text { May be challenging to determine } \\
\text { the value of the } \\
\text { contribution/impact of an } \\
\text { individual ecosystem service. }\end{array}$ & $\begin{array}{l}\text { Appropriate } \\
\text { under the } \\
\text { assumptions (i) } \\
\text { that the estimation } \\
\text { of the damage } \\
\text { costs reflects the } \\
\text { specific ecosystem } \\
\text { services being lost; } \\
\text { (ii) that the } \\
\text { services continued } \\
\text { to be demanded; } \\
\text { and (iii) that the } \\
\text { estimated damage } \\
\text { costs are lower } \\
\text { than potential } \\
\text { costs of abatement } \\
\text { or replacement. }\end{array}$ \\
\hline Averting behaviour & \begin{tabular}{|l} 
Prices are estimated \\
based on individuals \\
willingness to pay for
\end{tabular} & $\begin{array}{l}\text { Requires an understanding of } \\
\text { individual preferences and may be } \\
\text { difficult to link the activity of the }\end{array}$ & $\begin{array}{l}\text { Likely } \\
\text { inappropriate } \\
\text { since it relies on }\end{array}$ \\
\hline
\end{tabular}




\begin{tabular}{|c|c|c|c|}
\hline & $\begin{array}{l}\text { improved or avoided } \\
\text { health outcomes. }\end{array}$ & $\begin{array}{l}\text { individual to a specific ecosystem } \\
\text { service. }\end{array}$ & $\begin{array}{l}\text { individuals being } \\
\text { aware of the } \\
\text { impacts arising } \\
\text { from } \\
\text { environmental } \\
\text { changes. }\end{array}$ \\
\hline Restoration cost & $\begin{array}{l}\text { Refers to the estimated } \\
\text { cost to restore an } \\
\text { ecosystem asset to an } \\
\text { earlier, benchmark } \\
\text { condition. } \\
\text { Should be clearly } \\
\text { distinguished from the } \\
\text { replacement } \\
\text { method. }\end{array}$ & $\begin{array}{l}\text { The main issue here is that the costs } \\
\text { relate to a basket of ecosystem } \\
\text { services rather than a specific one. } \\
\text { More often used as a means to } \\
\text { estimate ecosystem degradation } \\
\text { but there are issues in its } \\
\text { application in this }\end{array}$ & $\begin{array}{l}\text { Inappropriate } \\
\text { since it does not } \\
\text { determine a price } \\
\text { for an individual } \\
\text { ecosystem service. }\end{array}$ \\
\hline Travel cost & $\begin{array}{l}\text { Estimates reflect the } \\
\text { price that consumers are } \\
\text { willing to pay in relation } \\
\text { to visits to recreational } \\
\text { sites. }\end{array}$ & $\begin{array}{l}\text { Key challenge here is determining } \\
\text { the actual contribution of the } \\
\text { ecosystem to the total estimated } \\
\text { willingness to pay. There are also } \\
\text { many applications of this method } \\
\text { with varying assumptions and } \\
\text { techniques being used with a } \\
\text { common objective of estimating } \\
\text { consumer surplus. Finally, some } \\
\text { travel cost methods include a value } \\
\text { of time taken by the household } \\
\text { which would be considered outside } \\
\text { the scope of the production } \\
\text { boundary used for accounting } \\
\text { purposes. }\end{array}$ & $\begin{array}{l}\text { Possibly } \\
\text { appropriate } \\
\text { depending on the } \\
\text { actual estimation } \\
\text { techniques and } \\
\text { whether the } \\
\text { approach provides } \\
\text { an exchange value, } \\
\text { i.er excludes } \\
\text { consumer surplus. }\end{array}$ \\
\hline Stated preference & $\begin{array}{|lr|}\text { Prices reflect } \\
\text { willingness } & \text { to pay from } \\
\text { either r contingent } \\
\text { valuation studies or } \\
\text { choice modelling. }\end{array}$ & $\begin{array}{l}\text { These approaches are generally } \\
\text { used to estimate consumer surplus } \\
\text { and welfare effects. Within the } \\
\text { range of techniques used there can } \\
\text { be potential biases that should be } \\
\text { taken into account. }\end{array}$ & $\begin{array}{l}\text { Inappropriate } \\
\text { since does not } \\
\text { measure exchange } \\
\text { values }\end{array}$ \\
\hline $\begin{array}{lr}\text { Marginal } & \text { values from } \\
\text { revealed } & \text { demand } \\
\text { functions } & \end{array}$ & $\begin{array}{l}\text { Prices are estimated by } \\
\text { utilising an appropriate } \\
\text { demand function and } \\
\text { setting the price as a } \\
\text { point on that function } \\
\text { using (i) observed } \\
\text { behaviour to reflect } \\
\text { supply (e.g. visits to } \\
\text { parks) or (ii) modelling a } \\
\text { supply function. }\end{array}$ & $\begin{array}{l}\text { This method can use demand } \\
\text { functions estimated through travel } \\
\text { cost, state preference, or averting } \\
\text { behaviour methods. The use of } \\
\text { supply functions has been termed } \\
\text { the simulation exchange method } \\
\text { (Campos \& Caparros, 2011) }\end{array}$ & $\begin{array}{l}\text { Appropriate since } \\
\text { aims to directly } \\
\text { measure exchange } \\
\text { values. However, } \\
\text { the creation of } \\
\text { meaningful } \\
\text { demand functions } \\
\text { and estimating } \\
\text { hypothetical } \\
\text { markets may be } \\
\text { challenging. }\end{array}$ \\
\hline
\end{tabular}

The ecosystem asset valuation methods presented in this way are the starting point used to develop specific methods for assessing water. These methods are also reflected in flood risk assessment. „It allows the application of various structural and non-structural measures to limit the risk, covering the periods before, during and after the flood event, and which are aimed at reducing (preventing) the potential impact of floods occurring and reducing (mitigating) the consequences. These measures are - upstream watershed changes(activities related to the increase of the forest area, mainly in the flat part of the basin), introduction of zoning in spatial planning (related to legislative 
measures to limit economic activity in high risk areas), emergency planning (preparation of adequate plans for the protection of the population based on the risk assessment), preparedness (awareness-raising and preparedness activities of the population in flood risk areas for adequate response), structural measures (related to construction of dykes and corrections of river sections for the protection of important economic sites).“ “5]

The calculation is a basic method of value estimation. It is manifested in the initial acquisition of the asset. In this way, all costs for the construction and commissioning of the asset are made clear. The value obtained is the value of the asset itself. Determining the useful life of an asset is another point that relates to answering the question - how much time can be used. The main problem in Bulgaria is the lack of such value, so the risks associated with the valuation of ecosystem assets are of particular interest. Given that we do not have the values of ecosystem assets built 20-30 years ago, discount factors should be used for analysis. This includes determining the net present value of ecosystem assets to date. Thus, if a decision is made to rent, sell, maintain the facilities, etc. their value will be known. Analyzing the relationship between financial and non-financial factors enables the calculation of water used for domestic, industrial, agricultural and natural needs.

\section{CONCLUSION}

The determination of the value of ecosystem assets related to water is characterized by the following uncertain events, namely: valuation of ecosystem services and physical assets, valuation of ecosystem assets and services, dynamics of changes in ecosystem services flows, the net present value of ecosystem assets, the future value of ecosystem services. This requires the development of a system of indicators related to water assessment and the overall infrastructure for its provisioning, transportation, and treatment. Applying appropriate valuation methods will determine the fair value of the water resource. This will lead somewhere to a reduced runoff as a result of unauthorized use and loss due to outdated infrastructure. Undoubtedly, the importance of water management will be of increasing importance to society. This will require the compilation of financial and non-financial valuation and calculation methods to work together.

\section{REFERENCES}

[1] Stats NZ (2019). Environmental-economic accounts: Sources and methods (second edition). Retrieved from www.stats.govt.nz.

[2] Stats NZ (2019). Environmental-economic accounts: Sources and methods (second edition). Retrieved from www.stats.govt.nz.

[3] Naydenov Kl. SMART CITIES - THE FUTURE OF URBAN PLANNING August 2018 DOI: 10.5593/sgemsocial2018/5.2/S19.025 Conference: 5th SGEM International Multidisciplinary Scientific Conferences on SOCIAL SCIENCES and ARTS SGEM2018

[4] SEEA Experimental Ecosystem Accounting: Technical Recommendations Consultation Draft - December 2015

[5] Zlatunova INTEGRATING FLOOD RISK ASSESSMENT INTO MANAGEMENT PRACTICE (CASE STUDY IN BULGARIA) September 2018 DOI: 10.18509/GBP.2018.55 Conference: 4th INTERNATIONAL SCIENTIFIC CONFERENCE GEOBALCANICA 2018 